\title{
Pengawasan Bank Asing di Indonesia
}

\author{
Sefriani
}

\begin{abstract}
Indonesia have no institution about foreign bank controlling specifically although the foreign banks have different characteristics from national banks. The rule of controlling for foreign banks in Indonesia have been spreading on several regulation for institution. It coud be said however that the regulation and controlling practice for foreign banks in Indonesia today have referrred to what have been assigned BIS to realize for controlling of the effective consolidation for multinational banks which have been operating in Indonesia.
\end{abstract}

\section{Pendahuluan}

Peratifikasian Final Act WTO tahiun 1994 diikuti pengundangan UU Nomor 10 Tahun 1998 tentang Pokok Pokok Perbankan telah memberi peluang yang sangat besar pada bank-bank asing untuk masuk ke Indonesia.

Sejalan dengan internasionalisasi pasar keuangan, cabang-cabang bank-bank asing yang melakukan kegiatan usahanya, di Indonesia juga mempunyai banyak cabang di negara-negara lain, tidak terbatas di negara asal bank tersebut saja. Hal ini mengakibatkan timbulnya resiko usaha dapat terjadi dimana saja di tempat beroperasinya bank-bank tersebut, termasuk di Indonesia Di samping itu, kecenderungan yang terjadi di dunia internasional adalah bahwa batas-batas kegiatan berbagai jenis lembaga keuangan menjadi semakin kabur. Hampir di seluruh dunia, nampak bahwa perusahaanperusahaan sekuritas semakin banyak melakukan jenis kegiatan jasa perbankan sementara bank-bank semakin banyak terlibat dalam jual beli saham. Perkembangan ini telah menciptakan lembaga keuangan baru yang melakukan kegiatan jasa keuangan yang sangat luas atau apa yang disebut sebagai Financial supermarket. Kesemuanya itu mengakibatkan resiko institusi keuangan khususnya perbankan menjadj semakin besar. $^{1}$

'BIS. 1996. The Supervision of Cross-Border Banking. Basle. Oktober. HIm.11 
Adanya kemajauan teknologi informasi dan transportasi serta deregulasi/liberalisasi pengaturan perbankan telah mengakibatkan pula perubahan-perubahan yang sangat besar dalam usaha perbankan dewasa ini. Kesemuanya itu juga merupakan tantangan tersendiri bagi otoritas pengawas perbankan dewasa ini. ${ }^{2}$

Pasca likuidasi terhadap 16 bank swasta nasional pada bulan Nopember 1997 , yang dilanjutkan pembekuan operasi bank-bank swasta nasional yang lain pada periodeperiode berikutnya, kepercayaan masyarakat pada perbankan swasta nasional sangat menurun. Hal ini nampak dari berlombalombanya masyarakat memindahkan rekening mereka ke bank-bank pemerintah serta bankbank asing yang ada di Indonesia. Benarkah bahwa bank asing selalu lebih baik, lebih aman, bebas dari resiko likuidasi, tidak seperti halnya bank swasta nasional dan bagaimana pengawasan terhadap bank asing di Indonesia akan dicoba dikaji melalui tulisan berikut.

\section{Kasus-kasus Perbankan internasional}

Dalam kaitannya dengan kepercayaan masyarakat pada bank-bank asing di atas, sebenarnya adalah tidak benar apabila menganggap bahwa bank asing selalu lebih aman daripada bank nasional. Pada dasarnya, kegiatan dan cara kerja bank dimanapun relatif sama. Faktor-fäktor resikonyapun relatif sama pula, seperti resiko kalah kliring, resiko kredit macet, resiko skandal, resiko bangkrut, sampai resiko dilikuidasi. Korea Selatan dan Thailand baru saja melikuidasi sejumlah banknya yang tidak sehat. Jepangpun baru saja melikuidasi bank nasional nomor dua terbesar di negara itu yang memiliki banyak cabang di luar negeri.Contoh lain adalah. Hongkong yang membekukan operasional Bank of Credit and Commerce International $(\mathrm{BCCl})$ beberapa tahun yang lalu karena skandal. $^{3}$

Berikut adalah beberapa contoh kasus yang menunjukkan bahwa bank asing yang besar dan kuat sekalipun, tidak lepas dari berbagai resiko kerugian yang dapat menjadikannya collaps (bangkrut). Kasus yang pertama adalah kasus Barings Bank, bank terbesar dalam sejarah perbankan Inggris yang sudah berusia 233 tahun, yang mengalami kerugian USD 1 billion akibat transaksi derivatifnya. Masalah yang terjadi pada Barings Bank tidak ditimbulkan oleh London sebagai tempat kedudukan kantor pusat kantor bank tersebut, melainkan oleh kantor cabangnya di Singapura, yang melakukan kegiatan transaksi tersebut. ${ }^{4}$

Pihak otoritas keuangan Singapura (The Monetray Authority of Singapore (MAS)) dalam penjelasannya pada pers menegaskan bahwa kerugian Barings Bank disebabkan oleh kurangnya pengawasan internal dari bank yang bersangkutan (the lack of internal control). Barings bank telah menempatkan Nice Leeson, karyawan yang melakukan transaksi

\section{2lbid}

${ }^{3}$ Njoman Suwidjana. "Mereka Relatif Bebas Kolusi." Dalam Infobank. Nomor 221. Januari 1998. HIm. 33

"Dian Ediana RAE. "Perbankan Indonesia Dalam Era Persaingan Abad 21." Dalam Majalah Pengembangan Perbankan, Nopember-Desember 1997. Him.36 
derivatif tersebut, pada posisi dimana tidak ada orang lain yang mengawasinya.sehingga dengan bebas ia melakukan transaksi derivatif dengan nasabah (client). dan order fiktif serta laporan yang penuh rekayasa. ${ }^{5}$

Kasus kedua adalah dicabutnya ijin usaha semua kantor cabang Daiwa.Bank.di.New York akibat kerugian sebesar USD:1,1 miliar yang disembunyikan kantor cabang bank tersebut selama kurun waktu: 1984-1995. Adapun kerugian dari kantor cabang. bank yang berkantor pusat di Osaka, Jepang tersebut adalah akibat kegiatan treasury dalam perdagangan obligasi yang memang beresiko tinggi. ${ }^{6}$

Kasus selanjutnya yang dapat dikemukakan adalah sekarat (collaps)-nya Continental Bank akibat kredit macet yang dideritanya. ${ }^{7}$ Manajemen bank tersebut, sejauh ini telah memusatkan pemberian kredit pada 1 sektor yaitu sektor energi, yang kemudian menjadi bermasalah ketika sektor tersebut mengalami kemunduran. Di. samping itu hal yang menambah kebangkrutan Continental Bank adalah sikap manajemen bank yang menggantungkan sumber dana pada pasar uang antar bank yang peka terhadap gejolak tingkat bunga. Bangkrutnya bank yang mempunyai banyak cabang di luar negeri tersebut juga menimbulkan masalah dalam. kaitannya dengan pengembalian dana nasabah yang tersimpan di bank tersebut, khususnya dana dari nasabah non-resident. ${ }^{8}$
Dari apa yang dikemukakan di atas terbukti bahwa, bank-bank asing tidak selalu lebih aman ketimbang bank-bank nasional sebagaimana anggapan sebagiañ besar orang Indonesia. Faktor-faktor resiko yang dihadápi bank-bank asing tersebut relatif sama dengan yang dihadapi bank-bank nasional:" Hal: yang'. membedakan bank-bank asing dengản bankbank nasional Indonesia pada-umumnya adalah permodalan, pengelolaan, dan sistem kontrol, serta pembinaan "óleh "otoritas moneternya. Modal bank asing biasanya jauh. lebih besar daripada bank-bank nasionali. Pengelolanya juga lebih berpengálamán sejalan dengan sejarah perbankan négerinya: Pengawasan dan pembinaan yang dilakúkan. oleh otoritas moneternya pun biasanya lebih. efektif, relatif bebas kolusi dan korupsi. ${ }^{9}$

Beberapa negara termasuk Hongkong dan. Singapura memberlakukan persyaratan dan pengawasan yang amat ketat bagi bank-bánk asing yang ingin membuka cabang. di negerinya. Persyaratan tersebut menyangkut, antara lain; modal minimum, kekayaan minimum, dan ada tidaknya sistem pengawasan dan pembinaan yang efektif di negeri asalnya. Semua itu untuk memastikan bahwa bankbank asing yang beroperasi di negeranya hanyalah bank-bank asing yang besar dan kuat: demi keamanan tabungan masyarákatnya yang ditaruh di cabang bank asing. ${ }^{10}, \ldots$

${ }^{54}$ Repercussions of Barings Disaster." Internet. 7 Maret 1995.

'Sugiharto, B. "Pelajaran yang Dapat Dipetik dari Kasus Perbankan di Luar Negeri. Dalam Majalah Pengembangan Perbankan. September-Oktober. 1998, HIm.17-18.

7lbid. HIm. $20-21$.

8/bid.'Hlm. 22.

9lbid.

${ }^{10} / \mathrm{bid}$. 


\section{Tujuan dan Sistem Pengawasan bank}

Tujuan dari dilakukannya pengawasan perbankan di tiap negara adalah hampir sama, yaitu:"

a. untuk melindungi deposan

b. memelihara stabilitas pasar keuangan

c: mendorong efisiensi dan daya saing dari sistem perbankan .

Tujuan di atas, dapat ditambahkan pula bahwa tujuan pengawasan perbankan adalah dalam rangka menjaga keamanan dan kesehatan bank maupun kesehatan sistem keuangan secara keseluruhan' sehingga diharapkan agar bank melaksanakan praktek perbankan yang sehat serta menjaga persaingan yang sehat di antara perbankan. ${ }^{12}$ Walaupun tujuan utama pengawasan perbankan di tiap negara hampir sama, namun terdapat perbedaan pola pengaturan dan pendekatan ataú teknik pengawasannya .

Pada kebanyakan negara, bank sentral terlibat dalam pengawasan; baik sebagai pengawas tunggal 'maupun' membagi tanggung jawab dengan lembaga atau badan lain. Di samping itu, di beberapa negara, pengawasan dilakukan oleh mega regulator, yang tidak hanya mengawasi lembaga perbankan, tetapi juga lembaga keuangan lainnya seperti asuransi dan perusahaan sekuritas. Swedia, Kanada, juga Singapura menerapkan pola mega regulator ini.

Pihak yang mendukung adanya fungsi pengawasan bank di bank sentral menyatakan. bahwa kebijakan moneter dan tugas pengawasan bank sangat erat kaitannya. Pencapaian tujuan masing-masing fungsi tersebut tidak dapat berjalan sendiri-sendiri.: Sementara itu, pihak yang menentang berpendapat bahwa tujuan kebijakan moneter dan pengawasañ bank dapat saling bertentangan. Sebagai contoh, pada saat likuiditas keuangan sangat tinggi, untuk mencapai stabilitas moneter, bank sentral akan melakukan kontraksi terhadap uang yang yang beredar. Bila dalam waktu bersamaan terjadi kesulitan perbankan, bank sentral dapat melakukan bantuan likuiditas terhadap bank yang mendapat kesulitan tersebut, hal ini akan berdampak sebaliknya yaitu ekspansi moneter. ${ }^{13}$

Dengan memperhatikan praktek-praktek yang dilakukan oleh beberapa negara lain, nampaknya tidak ada suatu "resep" sistem pengawasan yang manjur yang dapat diterapkan oleh semua negara dengan tingkat keberhasilan yang sama. Sistem ini masingmasing memiliki kekuatan dan kelemahan. Survei yang dilakukan IMF tahun 1991 menunjukkan bahwa dari 177 negara anggota IMF terdapat 145 negara yang pengawasan banknya dilakukan oleh bank sentral. Adapun 7 negara (Jepang, Kiribati, Korea, Austria, Dominica, Mexico, St.Lucia) pengawasan banknya dilakukan oleh Departemen Keuangan, dan 25 negara lainnya dilakukan oleh lembaga lain. ${ }^{14}$

"BIS. Guidelines for Effective Banking Supervision. Oktober 1997. Hlm.16

${ }^{12}$ Heru Soperaptomo. "Analisis Ekonomi Terhadap Hukum Perbankan. "Dalam Newsletter Nomor 2028I TahumVIII/Maret/1997. Hlm. 20.

${ }^{3}$ Dian Ediana RAE. "Peran Lembaga Pengawas Jasa Keuangan Pasca 2000. ${ }^{\text {HIm.42 }}$

14/bid. 


\section{Ketentuan Internasional tentang Pengawasan Bank Asing}

Ketentuan internasional yang dijadikan acuan negara-negara dalam pengaturan perbankan, antara lain yang dikeluarkan oleh Bank for International Settlement (BIS). Bank for International Settlement. BIS sebenarnya merupakan suatu bank yang berkedudukan di Basel, Swiss, dibentuk oleh 11 negara industri melalui Konferensi Den Haag pada Januari 1930. Dalam prakteknya bank ini sekaligus berfungsi sebagai suatu organisasi internasional yang berfungsi untuk memajukan kerjasama antar bank sentral negara-negara anggota dan untuk menyediakan fasilitasfasilitas kerjasama keuangan internasional. Dewasa ini dengan anggota yang telah mencapai sekitar 120 bank sentral, keberadaan BIS menjadi semakin penting. Aturan-aturan yang dikeluarkan oleh BIS menjad acuan hampir seluruh bank sentral yang ada di dunia. ${ }^{15}$

Dalam kaitannya dengan pengawasan bank, BIS melalui The Basel Committee on Banking Supervision pada September 1997 menetapkan Prinsip-prinsip dasar pengawasan bank yang efektif terdiri dari 25 persyaratan yang dapat dikelompokkan ke dalam 7 aspek.

Aspek yang pertama adalah Pra kondisi bagi pengawasan yang efektif. Aspek ini menekankan perlunya kejelasan wewenang, tanggung jawab, tujuan yang jelas, bersifat independen, dan memiliki sumber daya yang cukup bagi badan-badan yang terlibat dalam pengawasan bank. ${ }^{16}$

Aspek yang kedua adalah perijinan dan struktur. Aspek ini mencakup kejelasan mengenai kegiatan yang dijjinkan, kriteria perijinan, otoritas yang mengkaji dan menolak usul, serta otoritas untuk menetapkan kriteria. ${ }^{17}$

Aspek yang ketiga adalah mengenai prinsip kehati-hatian (prudentia). Aspek ini mencakup ketentuan mengenai kecukupan modal, standar kredit dan monitoring, kebijakan dan prosedur evaluasi terhadap kualitas aset, sistem informasi manajemen bank. ketentuan pinjaman terkait (BMPK), Monitoring terhadap resiko, Memiliki sistem yang memadai untuk memantau situasi pasar, mempunyai proses pengendalian resiko manajemen yang komprehensif, sistem pengendalian internal serta meningkatkan kode etik profesional

Aspek yang keempat adalah metode pengawasan bank yang berkesinambungan (on going supervision). Aspek ini menetapkan harus dilaksanakannya pemeriksaan (on-site) dan pengawasan (off-site). Di samping itu badan pengawas harus senantiasa melakukan hubungan atau diskusi dengan manajemen bank, mempunyai teknik untuk melakukan analisis datallaporan, mempunyai independensi, serta mampu melakukan pengawasan secara konsolidasi.

${ }^{15} \mathrm{BIS}$. "The Bank for International Settlement: Profile of an International Organisation." Basle. Switzerland. Juni 1999 BIS . Internet: http: www.bis.rog. html. Juni 1999. HIm. 6.

${ }^{16} \mathrm{BIS}$. The Core Principles for Effective Banking Supervision. September 1997. HIm. 39.

${ }^{17} \mathrm{lbid}$. HIm. 40. 
Aspek yang kelima adalah Informasi perbankan. Dalam aspek ini setiap bank harus mengupayakan. catatan-catatan yang memadai yang dihasilkan sesuai dengan kebijakan akunting yang konsisten sehingga memungkinkan pengawas untuk memperoleh pandangan yang obyektif atas kondisi keuangan dan profitabilitas bank. Bank-bank harus menerbitkan laporan keuangan berkala secara objektif mencerminkan kondisinya. ${ }^{18}$

Aspek yang keenam adalah mengenai wewenang formal pengawas. Dalam aspek ini pengawas harus memiliki wewenang yang memadai dan jelas untuk melakukan tindakan korektif jika bank gagal memenuhi standarstandar prudensial atau jika kepentingan para deposan terancam. ${ }^{19}$

Aspek yang ketujuh adalah aturan dan kerjasama pengawasan internasional (crossborder banking). Aspek ini menekankan pentingnya peranan supervisor negara asal (home state) dan setempat (host state), perlunya pengawasan secara konsolidasi atau global dan wewenang untuk bertukar informasi dengan para pengawas lainnya serta perlunya penerapan standar yang sama antara bank lokal dengan bank asing..$^{20}$

Dewasa ini hampir semua institusi pengawas bank di seluruh dunia telah atau mulai menerapkan standar pengawasan. berdasarkan 25 prinsip dasar. Namun demikian, penerapannya tidak dilakukan secara kaku, tetapi sangat bervariasi sesuai dengan kondisi objektif yang ada dalam sistem keuangan di masing-masing negara. ${ }^{21}$

Dalam kaitannya dengan pengawasan bank asing koordinasi dan kerjasama antara otoritas pengawas tuan rumah dan negara asal merupakan syarat utama untuk pengawasan keberadaan dan operasional bank asing yang efektif. Hal ini sejalan dengan yang direkomendasikan oleh BIS dalam laporannya mengenai Pengawasan bank lintas batas. ${ }^{22}$

Untuk efektifnya pengawasan terhadap bank-bank multinasional, akses informasi dua arah antara otoritas tuan rumah dan negara asal benar-benar harus berjalan dengan baik dan intensif. Otoritas pengawas tuan rumah harus menyadari bahwa otoritas pengawas negara asal harus mendapat informasi secepat mungkin berkaitan dengan setiap masalah serius yang timbul terhadap banknya yang beroperasi di negara tuan rumah. Demikian sebaliknya, otoritas negara asal harus menginformasikan setiap permasalahan yang timbul yang dapat mempengaruhi kesehatan bank-bank multinasionalnya itu. ${ }^{23}$

\section{i8/bid.}

${ }^{19} / \mathrm{bid}$.

20lbid. HIm. 41.

${ }^{21}$ Toto Zurianto. "Perspektif Pengaturan dan Pengawasan Bank di Indonesia." Dalam Majalah Pengembangan Perbankan. IBI. Mei-Juni. 1998. HIm. 56.

${ }^{22} \mathrm{BIS}$. "The Supervision of Cross-Border Banking." Report by a Working Group Comprised of Members of basle Committee on Banking Supervision and The Offshore Group of Banking Supervisors. Basle. Oktober 1996. HIm. 2.

${ }^{23}$ BIS. Principles for the Supervision of Bank's. Foreign Establishments. Mei, 1983. Dokumen ini lebih dikenal sebagai The Basle Concordat 1983. 
Pada tahun 1992 BIS mengeluarkan ketentuan yang dikenal sebagai standar minimum pengawasan perbankan internasional dan pendirian bank-bank multinasional atau yang dikenal juga dengan istilah bank. lintas batas (cross border banking). Ketentuan ini memuat 4 prinsip utama yaitu:

1. Semua bank multinasional. harus diawasi oleh otoritas negara asal (home country authority) yang mempunyai kemampuan melakukan pengawasan konsolidasi

2. Pendirian bank multinasional harus dengan ijin terlebih dahulu baik dari otoritas pengawas tuan rumah maupun negara asal

3. Otoritas pengawas berhak atas informasiinformasi berkaitan dengan keberadaan dan operasional bank-barik multinasional.

4. Apabila otoritas tuan rumah berkeyakinan bahwa 3 standar minimum di atas tidak terpenuhi, ia harus melakukan tindakan kehati-hatian termasuk melarang pendirian bank-bank multinasional tersebut di wilayah yurisdiksinya.

Melalui standar minimum di atas diharapkan di masa yang akan datang tidak ada bank múltinasional yang dapat beroperasi tanpa tunduk pada pengawasan konsolidais yang efektif.

\section{Pengaturan dan Praktek Pengawasan bank aisng di Indonesia}

Keraguan tentang kemampuan B! sebagai pengawas perbankan di Indonesia nampak dengan terjadinya perubahan sistem pengawasan perbankan di lindonesia. UU Nomor 23 Tahun 1999 tentang Bank Indonesia yang menggantikan UU Nomor 13 tahun 1968 tentang Bank Sentral menyebutkan báhwa tugas mengawasi bank akan dilakukan oleh lembaga pengawas jasa keuangan yang independen, yang akan dibentuk dengan undang-undang, paling lambat tanggal 31 Desember 2002 yang akan datang. Fungsi pembinaan dan pengaturan tetap akan dilakukan oleh Bank Indonesia. Lembagà pengawas jasa keuangan yang dimaksud, ini, nantinya akan mengawasi lembaga perbankan dan semua lembaga keuangan non-bank termasuk pasar modal. ${ }^{24}$

Dalam kaitannya dengan pengawasan bank asing , sampai saat ini Indonesia beium memiliki peraturan khusus mengenai pengawasan bank asing. ${ }^{25}$. Pengaturan terhadap pengawasan bank secara umum di Indonesia tersebar dalam beberapa peraturan perundang-undangan. Pengawasan terhadap bank asing dilakukan bersama-sama dan dengan sistem serta mekanisme yang relatif sama dengan pengawasan yang dilakukan terhadap bank nasional. Hanya tim pengawasnya saja yang berbeda. Ada tim pengawas untuk bank umum nasional dan ada

\section{${ }^{24}$ lbid}

${ }^{25}$ Amerika Serikat memiliki International Banking Act yang mengatur bank-bank Amerika yang beroperasi di luar negeri maupun bank-bank asing yang beroperasi di Amerika Serikat. 
pula tim pengawas untuk bank asing. Sampai dengan tahun 1994, satuan kerja pengawasan di Bank Indonesia dipisahkan dari satuan kerja pemeriksaan. Namun, sejak tahun 1994 sampai dengan 1997 kedua satuan kerja tersebut digabung dalam satu kelompok "dedicated team" dengan spesialisasi pengawas bank. Selanjutnya, sejak tahun 1998 dilakukan pemisahan kembali antara satuan kerja pengawasan dan pemeriksaan bank.

Selama ini pengawasan terhadap bankbank asing di Indonesia relatif lebih mudah dilakukan dibandingkan dengan pengawasan terhadap bank nasional. Hal ini dikarenakan jumlah bank yang masih sedikit serta, lebih tertibnya bank-bank asing tersebut dalam segala hal dibandingkan bank-bank nasional. Kondisinya tentu tidak akan statis terus seperti saat ini seiring dengan diberikannya kesempatan yang sangat besar bagi pihak asing untuk masuk ke pasar perbankan Indonesia. ${ }^{26}$

. Sama seperti yang dilakukan terhadap bank nasional, dalam melakukan pengawasan terhadap bank asing, otoritas pengawas indonesia (dalam. hal, ini Bank Indonesia) selama ini melakukam dua macam pendekatan, yaitu:27

a. pengawasan tidak langsung (off-site supervision), menggunakan laporan mingguan, laporan triwulanan, dan laporan tahunan serta data atau informasi dari sumber-sumber lainnya. b. Pengawasan langsung (on-site supervision), dilakukan dengan cara mengunjungi dan memeriksa kantor bank secara langsung secara periodik maupun insindental sesuai kebutuhan.

Mengingat bahwa bank asing merupakan kesatuan usaha yang berbadan usaha asing, berkantor pusat di luar negeri dan dengan kegiatan usaha yang terintegrasi dengan kantor pusatnya, maka pengawasan yang dilakukan oleh Bank Indonesia terdiri dari dua macam. Pengawasan yang dimaksud adalah pengawasan yang dilakukan oleh Bank Indonesia sendiri selaku otoritas tuan rumah (host state authority) serta pengawasan yang dilakukan bersama-sama atau kerja sama dengan otoritas negara asal bank-bank asing yang bersangkutan (home state:authority) ${ }^{28}$

Dalam hal pengawasan bentuk pertama, ada beberapa hal yang penting untuk dikemukakan, yaitu masalah perijinan, tingkat kesehatan bank, kegiatan usaha, transfer devisa, serta perlindungan terhadap nasabah Indonesia.

Dengan ketentuan perijinan yang ketat diharapkan sudah merupakan pengawasan awal terhadap bank-bank asing yang ada di Indonesia. Dewasa ini , sepuluh kantor cabang bank asing yang beroperasi di Indoriesia merupakan bank-bank yang mempunyai peringkat dan reputasi terbaik di tingkat internasional. Mempunyai modal, sumber daya manusia, teknologi, dan managemen yang kuat, serta memiliki daya saing tinggi.

\footnotetext{
${ }^{26} /$ bid

${ }^{27}$ Toto Zurianto. Op.Cit. HIm. 58

${ }^{28} /$ bid
} 
- Sampai saat ini misalnya, tidak ada bank asing di Indonesia yang memiliki CAR di bawah $8 \%$ : CAR yang dimiliki bank-bank tersebut berkisar antara 10,65\% sampai dengan $17,85 \% .{ }^{29}$ Laporan The Wall Street Journal 27 September 1999 yang menyebutkan bahwa 7 di antara 10 bank asing yang ada di Indonesia saat ini masuk daläm 100 bank terbesar di dunia. Deutsche Bank (Jerman) misalnya, dilaporkan menduduki peringkat pertama dunia dengan aset US\$ 705,710 juta. Berikutnya adalah Bank of Tokyo Mitsubishi (Jepang) yang menduduki peringkat 3, Bank of Amerika (USA) di peringkat 4, ABN Amro (Belanda) di peringkat 6 , Hongkong and Shanghai Bank Corporation (HSBC) di peringkat 7, Chase Manhattan (USA) di peringkat 23 dan Citibank (USA) di peringkat 25 dunia. $^{30}$

Kedua adalah pengawasan tingkat kesehatan bank (selanjutnya disingkat TKB). Penilaian TKB merupakan suatu proses yang relatif kompleks. Tidak hanya mensyaratkan pemahaman yang mendalam terhadap berbagai faktor yang mempengaruhi usaha bank, tetapi juga memerlukan data dan informasi yang lengkap dan akurat serta suatu metode yang telah teruji validitasnya. ${ }^{31}$ Pada dasarnya TKB ini merupakan suatu sistem deteksi dini (early warning system) untuk mengidentifikasi berbagai masalah potensial dan resiko yang dihadapi bank.

Baik terhadap bank nasional maupun bank asing, konsep penilaian TKB yang dilaksanakan oleh Bank Indonesia mengacu pada prinsip kehati-hatian perbankan (prudential banking principles) sebagaimana yang diatur oleh Bank for International Settlement (BIS) yang dianut secara internasional oleh negara-negara anggotanya. Tingkat kesehatan suatu bank asing merupakan indikator penilaian pengelolaan bank tersebut dalam suatu periode tertentu. Dalam hal ini, Bank Indonesia sebagai bank sentral telah menetapkan beberapa kètentuan tentang penilaian TKB, antara lain aspek permodalan, kualitas asset, kualitas manajemen, rentabilitas, likuiditas, solvabilitas, dan aspek lain yang berkaitan dengan kegiatan usaha bank seperti ketentuan tentang Batas Maksimum Pemberian Kredit (BMPK) dan ketentuan tentang Pósisi Devisa Netto (Net Open Position) yang semuanya berlandaskan pada prinsip kehati-hatian. ${ }^{32}$

Dalam kaitannya dengan bank asing, dalam penilain TKB ini bank tersebut diperlakukan seolah terpisah dengan bank induknya. Dengan demikian cabang bank

\footnotetext{
29Laporan keuangan Bank Indonesia Desember 1998-September 1999.

${ }^{30}$ "The World's 100 Largest Banks." Dalam The Wall Street Journal, World Business-WSJ Interactive Edition. 27 September 1999.

${ }^{31}$ Penilaian TKB diatur:oleh BI dalam Surat Keputusan (SK) Direksi BI No.30/11/KEP/DIR dan Surat Edaran (SE) BI No.30/2/UPPB masing-masing perihal Tatacara Penilaian Tingkat Kesehatan Bank Umum tanggal 30 April 1997 dan SK BI No.30/277/KEP/DIR dan SE BI No.30/23/UPPB perihal Perubahan Tatacara Penilaian Tingkat Kesehatan Bank Umum dan masing masing tertanggal 30 April 1997 dan 19 Maret 1998.

${ }^{32}$ Hifni Kasian. "Menilai Kesehatan Bank." Dalam Majalah Pengembangan Perbankan. Nomor 72. JuliAgustus. 1998. Hlm. 40.
} 
asing yang ada di Indonesia memiliki dan melakukan pembukuan, administrasi, dan pelaporan sendiri. Bank Indonesia hanya berhak menilai TKB yang bersangkutan berdasarkan laporañ dan kondisi cabang bank yang ada di Indonesia saja. Dengan cara ini banyak kelemahannya, mengingat pada kenyataannya bank asing yang ada di Indonesia melakukan kegiatan usaha yang terintegrasi dengan kantor pusatnya. Kerugian dalam jumlah besar yang. menimpa bank tersebut di cabang yang terletak dí negara lain atau mungkin di negara asalnya tentu akan mempengaruhi tingkat kesehatan bank tersebut secara keseluruhan. Untuk itulah koordinasi dan kerjasama dalam hal pengawasan bank dengan otoritas negara asal bank yang bersangkutan sangatlah diperlukan. ${ }^{33}$

Ketiga adalah pengawasan kegiatan usaha. Dalam praktek ternyata bank-bank asing yang ada di Indonesia selama ini jauh lebih hati-hati dan tertib dalam menjalankan kegiatan usahanya dibandingkan dengan bank nasional. Hal ini menurut tim pengawas bank asing di Bank Indonesia dikarenakan mereka sudah terbiasa dengan kondisi yang berlaku di "negaranya yang serba teratur (regulated). Sebagai contoh dapat dikemukakan bahwa bank-bank asing tersebut senantiasa meminta ijin kepada otoritas atau pejabat berwenang di Bank Indonesia untuk mempresentasikan produk jasa perbankannya yang terbaru sebelum dipasarkan pada masyarakat luas. Selanjutnya adalah mengenai pengawasan terhadap transfer atau lalu lintas devisa. Hal ini penting untuk dikemukakan mengingat banyaknya kecurigaan yang ditujukan pada bank asing telah melakukan pelarian modal (capital flight) yạng sangat dibutuhkan Indonesia ke negara asalnya.

Dalam kaitannya dengan lalu lintas devisa ini, UU Nomor 24 Tahun 1999 tentang Lalu Lintas Devisa dan Sistem Nilai Tukar menganut sistem devisa bebas. Setiap penduduk dapat dengan bebas memiliki dan menggunakan devisa yang dimilikinya. Penduduk yang memperoleh dan memiliki devisa tidak wajib menjualnya kepada negara. Kebijakan devisa bebas diambil oleh Pemerintah Indonesia dengan maksud untuk mengimbangi semakin merosotnya jumlah investor asing ke Indonesia ${ }^{34}$

Dalam kaitannya dengan kegiatan lalu lintas devisa yang dilakukan oleh bank asing, Bank Indonesia mewajibkan bank asing yang berkedudukan di Indonesia untuk menyampaikan keterangan dan data kepada Bank Indonesia mengenai kegiatan lalu lintas devisa yang dilakukannya secara lengkap, benar dan tepat waktu. ${ }^{35}$ Laporan tersebut merupakan laporan gabungan dari seluruh kantor operasionalnya yang berkedudukan di Indonesia. Keterangan dan data yang wajib dilaporkan oleh bank tersebut meliputi: ${ }^{36}$

${ }^{33}$ Narni Purwati \& Alfano Gokmatua. "Beberapa Ketentuan Bank Sentral Tentang. Kesehatan Bank." Dalam Majalah Pengembangan Perbankan. Nomor 72. Juli-Agustus. 1998. HIm. 51.

${ }^{34}$ Pasal 2 UU Nomor 24 Tahun 1999 tentang Lalu Lintas Devisa dan Sistem Nilai Tukar.

${ }^{35}$ Peraturan Bank Indonesia Nomor:1/9/PBI/1999 tanggal 28 Oktober 1999 tentang Pemantauan Kegiatan Lalu Lintas Devisa Bank dan Lembaga Keuangan Non Bank, Pasal 2.

${ }^{36} \mathrm{Ibid}$. Pasal 4. 
a. perpindahan devisa melalui bank baik untuk kepentingan bank maupun nasabah, yaitu transaksi:

1. penerimaan dan pembayaran ke luar negeri baik dalam rupiah maupun valuta asing

2. penerimaan dan pembayaran kepada penduduk di dalam negeri baik dalam rupiah maupun valuta asing

3. penerimaan dan pembayaran di dalam negeri anatra penduduk dalam valuta asing.

b. Posisi aset dan kewajiban finansial luar negeri bank.

Khusus untuk transaksi di atas US\$ 10:000,00 (sepuluh ribu dolar Amerika Serikat) atau ekuivalennya dilaporkan secara rinci , mencakup antara lain keterangan mengenai pelaku dan hubungan keuangan antar pelaku transaksi serta tujuan transaksi. Adajpun untuk transaksi sampai dengan US\$ 10.000,00 (sepuluh ribu dolar Amerika Serikat) atau equivalennya, dilaporkan secara gabungan (lump sum) tanpa harus dilengkapi dengan keterangan mengenai pelaku dan hubungan keuangan antar pelaku transaksi serta tujuan transaksi ${ }^{37}$.

Di sini nampak bahwa bank termasuk di dalamnya bank asing hanya dikenakan wajib lapor transaksi kegiatan lalu lintas devisanya saja. Tidak ditemukan pembatasan jumlah devisa yang ditransaksikan. Penduduk atau pelaku usaha yang lain (tidak hanya bank asing), memang dapat melakukan pelarian modal ke luar negeri, bilamana ia menginginkan hal tersebut. Pada kenyataannya hal ini memang banyak terjadi. Pemerintah Indonesia megetahui bahwa sebagian besar bank-bank asing melakukan pelarian modal (capital flight), khususnya saat puncak krisis moneter di Indonesia 1997-1998 yang lalu dengan cara mengirimkan uang yang berhasil ditariknya dari nasabah Indonesia ke negara asainya. Berdasarkan ketentuan yang ada tidak banyak yang dapat dilakukan pemerintah untuk mencegah hal tersebut.

Ketentuan wajib lapor yang ditetapkan dalam UU Nomor 24 Tahun 1999 pada dasarnya sudah merupakan langkah baru.bagi Indonesia yang tidak ditemukan dalam UU sebelumnya.. Dengan adanya ketentuan wajib lapor, diharapkan pemerintah memiliki alat dan data untuk memonitor transaksi serta lalu lintas devisa, meskipun tetap tidak dapat diandalkan untuk mencegah terjadinya pelarian modal. Amerika Serikat, Jepang, Korea Selatan, dan Taiwan sudah sejak lama menganut sistem devisa di mana mekanisme pengendalian atau monitoring devisa dilakukan seperti halnya sistem yang sedang atau mulai diterapkan oleh Indonesia.

Dalam kaitannya dengan pengawasan terhadap bank asing, di samping untuk mendukung perumusan dan peningkatan efektivitas kebijakan moneter, pada dasarnya pelaporan yang wajib dilakukan oleh bankbank asing tersebut lebih didasarkan alasan untuk tujuan pengawasan dan penerapan prinsip kehati-hatian sebagai salah satu upaya

${ }^{37}$ Surat Edaran Bank Indonesia No.1//DSM tanggal 28 Desember 1999 perihal Pelaporan Kegiatan Lalu Lintas Devisa oleh Bank, Bagian IIA. 
untuk meminimalkan resiko usaha dalam pengelolaan bank daripada untuk mencegah terjadinya pelarian modal. Transaksi di bidang devisa memang mịasuk kategori kegiatan berisiko tinggi, yang dapat menimbulkan kerugian dalam jumlah yang besar pada bank pelaku yang bersangkutan apabila tidak dilakukan dengan hati-hati. Dengan dilakukannya pengawasan, maka dapat dilakukan pencegahan secara dini terhadap bahaya kebangkrutan bank asing yang bersangkutan.

Keempat adalah perlindungan terhadap nasabah Indonesia Hal ini dapat dilakukan Bank Indonesia dengan pencabutan ijin usaha bank asing baik atas pertimbangan Bank Indonesia maupun atas permintaan negara asal serta persyaratan asuransi. Hasil penelitian menunjukkan bahwa ke-10 bank asing yang ada dewasa ini di Indonesia sudah mengasuransikan dana nasabahnya ke lembaga asuransi di negara asal masingmasing, baik yang dibentuk oleh pemerintah maupun swasta. Nasabah bank-bank asing asal Amerika Serikat misainya saat ini akan dijamin dananya oleh Federal Deposit Insurance Company sampai batas maksimum US\$ 100.000 .38

Dengan adanya jaminan asuransi ini, nasabah penyimpan dana pada bank-bank yang ada di Indonesia memperoleh jaminan dari lembaga asuransi bahwa dananya akan dijamin pembayarannya sampai batas maksimum yang telah ditetapkan apabila bank asing yang bersangkutan tidak mampu membayar kewajibannya pada para krediturnya.

Masih dalam kaitannya dengan pengawasan bank asing, sejauh ini Indonesia sering melakukan pertemuan-pertemuan bilateral dengan otoritas pengawas negara asal bank-bank asing yang ada di Indonesia untuk melakukan koordinasi dan kerjasama, juga pertukaran informasi mengenai bank-bank asing di indonesia. Informasi dimaksud khususnya mengenai kondisi kesehatan bank asing yang bersangkutan.

Di samping itu Indonesia juga aktif menjadi anggota serta menghadiri forum-forum pertemuan bank-bank sentral, baik untuk tingkat regional seperti SEACEN (Southeast Asian Central Banks) maupun di tingkat internasional seperti forum-forum pertemuan yang disponsori oleh BIS (Bank for International Settlement). Dalam forum-forum ini dibahas masalah-masalah perbankan internasional, pengembangan sumber daya manusia, teknologi perbankan, perlindungan dana nasabah, dan masalah-masalah aktual lainnya yang dihadapi perbankan internasional. ${ }^{39}$

Dapat ditambahkan pula bahwa Indonesia juga sudah menerapkan prinsip yang direkomendasikan oleh BIS di mana bank-bank asing yang akan membuka cabang di Indonesia harus mendapatkan ijin dari Bank Indonesia serta mendapatkan rekomendasi dari otoritas moneter negara asalnya. Dengan demikian dapat disimpulkan bahwa tanpa rekomendasi atau ijin dari otoritas negara asalnya bank asing tersebut tidak akan mendapat ijin dari Bank Indonesia untuk mendirikan cabang di Indonesia.

${ }^{38}$ Catherine England. "Banking on Free Markets." 5 September 1999. internet. http:/www.cato.org/ pubs/regulation/reg18n2b.htmI .

${ }^{39} \mathrm{BIS}$. "The Bank for International Settlement: Profile of an international organisation." Loc.Cit. 
Hal baru yang merupakan kemajuan bagi pengawasan bank asing di Indonesia adalah dimungkinkannya otoritas moneter negara asal bank asing melakukan pemeriksaan langsung (on-site inspectation) pada kantor cabang banknya yang ada di Indonesia setelah mendapat ijin terlebih dahulu dari Bank Indonesia ${ }^{40}$ Selama ini yang dapat dilakukan oleh otoritas negara asal adalah sebatas melakukan pemerikssaan tidak langsung (offsite inspection). Sampai saat inipun masih banyak negara berkembang yang melarang dilakukannya-inspeksi atau pemeriksaan langsung oleh otoritas negara asal terhadap bank-banknya yang beroperasi di wilayah atau yurisdiksinya. lasan yang dikemukakan mereka antara lain khawatir akan ikut campurnya otoritas negara lain terhadap kebijakan moneter dan perbankan nasional, akan terganggunya kedaulatan negara,serta akan bertentangan dengan prinsip kerahasian bank apabila mengijinkan dilakukannya inspeksi langsung oleh otoritas negara asal.

Larangan tersebut di atas menurut BIS sedikit banyak tentu akan mengganggu terwujudnya pengawasan konsolidasi yang efektif dalam perbankan lintas batas. Untuk itu, BIS merekomendasikan negara-negara yang bersangkutan untuk segera mengubahnya demi efektif dan tuntasnya pengawasan konsolidasi perbankan lintas batas (effective comprehensive consolidated supervision on cross border banking). ${ }^{41}$
Namun demikian, yang direkomendasikan oleh BIS, apabila otoritas tuan, rumah mempunyai alasan atau dugaan kuat bahwa inspeksi atau pemeriksaan langsung yang akan dilakukan oleh otoritas negara asal tidak untuk tujuan pengawasan banknya (non-supenvisory purposes), ia berhak untuk menolak atau menunda memberikan ijin dilakukanya inspeksi langsung tersebut. ${ }^{42}$

BIS juga memberikan dua alternatif lain bagi otoritas tuan rumah yang tidak mengijinkan dilakukannya inspeksi langsung oleh .otoritas negara asal. Alternatif pertama adalah bahwa inspeksi langsung dilakukan oleh otoritas tuan rumah, tetäpi dengan arahan dan sesuai dengan permintaan otoritas negara asal. Alternatif kedua adalah bahwa inspeksi langsung dilakukan oleh otoritas negara asal, tetapi dengan kawalan atau pengawasan langsung (accompany) dari otoritas negara tuan rumah. Yang terpenting menurut BIS adalah adanya kerjasama yang baik dan intensif dalam melakukan pengawasan antara otoritas kedua negara. ${ }^{43}$

Dalam kaitannya dengan hal ini saat ini Indonesia hanya mewajibkan dilaporkannya hasil pemeriksaan kepada Bank Indoneșia segera setelah pemeriksaan dilakukan serta mensyaratkan adanya asas timbal balik dengan otoritas negara asal bagi diberikannya ijin pemeriksaan atau inspeksi langsung. ${ }^{44}$

${ }^{40}$ Peraturan Bank Indonesia Nomor 2/6/2000 tentang Persyaratan dan Tata Cara pemeriksaan bank, Pasal 15.

${ }^{41 B I S . ~ " T h e ~ S u p e r v i s i o n ~ o f ~ C r o s s-B o r d e r ~ B a n k i n g . " ~ O p . C i t . ~ H I m . ~} 4$.

${ }^{42} \mathrm{lbid}$.

${ }^{43} /$ bid. HIm. 5 :

${ }^{44}$ Peraturan Bank Indonesia Nomor 2/6/PBI/2000 Tentang Persyaratan dan Tata Cara Pemerikaan Bank, Pasal 18 \& Pasal 15(5). 
Dengan dikeluarkannya kebijakan baru tersebut di atas nampak bahwa Indonesia sudah berupaya melaksanakan prinsip prudéntial banking yang disyaratkan oleh B.I demi terwujudinya pengawwasan konsolidasi yảng efektif terhadap bank-bank multinasional yang ada di Indonesia.

\section{Simpulan}

Sampai saat inị Indonesia belum memiliki pengaturan tentang pengawasan bank asing secara khusus meskipun bank ini' memiliki karakteristik yang berbeda dengan bank nasional: Pengaturan mengenai pengawasan bank asing di Indonesia tersébar dalam beberapa peraturan perundang-undangan. Meskipun demikian dapat' dikatakan bahwa. pengaturan dan praktek pengawasan bänk asing di Indonesia saat ini telah merujuk pada apa yang ditetapkan BIS untuk mewujudkan pengawasan konsọlidasis yang efektif terhadap. bank-bank multinasional yang beroperasi di Indonesia." "a'

\section{Daftar Pustaka}

"Repercussions of Barings Disaster," Internet. 7 Maret 1995

"The World's 100 Largest Banks." Dalam The Wall Street Journal, World Business-WS J Interactive Edition. 27 September 1999.

BIS. "The Bank for International Settlement : Profile of an International Organisation." Basle. Switzerland. Juni 1999 BIS . Internet: http: www.bis.rog. html. Juni 1999.
. "The Supervision of Cross-Border. Banking." Report by a Working Group Comprised of Members of basle Committee on Banking Supervision and The Offshore Group of Banking Supervisors. Basle. Oktober 1996.

1996. The Supervision of Cross-Border Banking. Basle. Oktober.

: Guidelines for Effective Banking Supervision. Oktober 1997.

Principles for the Supervision of Bank's Foreign Establishments. Mei, 1983.

. The Core Principlés for Effective Banking Supervision. September 1997.

Dian Ediana RAE. "Perbankan Indonesia Dalam Era Persaingan Ábad 21." Dalam Majalah Pengembangan Perbankan, Nopember-Desember 1997.

England; Catherine." "Banking on Free Mar"kets." 5 September 1999. internet. http:/www.cato.org/pubs/regulation/ reg18n2b.htm!

Kasian, Hifni. "Menilai Kesehatan Bank." Dalam Majalah Pengembangan 'Perbankan: Nomor 72. Juli-Agustus. 1998.

Purwati, Narni \& Alfano Gokmatua. "Beberapa Ketentuan Bank Sentral Tentang . Kesehatan Bank." Dalam Majalah Pengembangan Perbankan. Nomor 72. Jull-Agustus. 1998.

RAE, Dian Ediana. "Peran Lembaga Pengawas Jasa Keuangan Pasca 2000:" 
Soperaptomo, Heru. "Analisis Ekonomi Terhadap Hukum Perbankan." Dalam News/etter Nomor 2028/TahumVIIII Maret/1997.

Sugiharto, B. "Pelajaran yang Dapat Dipetik dari Kasus Perbankan di Luar Negeri. Dalam Majalah Pengembangan

Perbankan. September-Oktober. 1998.

Suwidjana, Njoman. "Mereka Relatif Bebas Kolusi." Dalam Infobank. Nomor 221. Januari 1998.

Zurianto, Toto. "Perspektif Pengaturan dan Pengawasan Bank di Indonesia." Dalam Majalah Pengembangan Perbankan. IBI. Mei-Juni. 1998.

UU Nomor 13 Tahun 1968 tentang Perbankan

UU Nomor 7 Tahun 1992 tentang PokokPokok Perbankan.

UU Nomor 7 Tahun 1994 tentang Pengesahan Agreement Establishing The World Trade Organization

UU Nomor 10 Tahun 1998 tentang Perubahan
Atas Undang-Undang nomor 7 Tahun 1992 Tentang Pokok-Pokok Perbankan

UU Nomor 23 Tahun 1999 tentang Bank Indonesia.

UU Nomor 24 Tahun 1999 tentang Lalu Lintas Devisa dan Sistem Nilai Tukar.

PP Nomor 3 Tahun 1968 tentang Bank Asing PP Nomor 24 Tahun $1999^{\circ}$ tentang Ketentuan dan tata cara pembukaan kantor cabang, kantor cabang pembantu, dan kantor perwakilan dari bank yang berkedudukan di luar negeri

PP Nomor 25 Tahun 1999 tentang Pencabutan Izin Usaha, Pembubaran, Dan Likuidasi Bank.

Peraturan Bank Indonesia Nomor :1/9/PBI/ 1999 tanggal 28 Oktober 1999 tentang Pemantauan Kegiatan Lalu Lintas Devisa Bank dan Lembaga Keuangan non Bank

Peraturan Bank Indonesia Nomor 2/6/PBI/2000 tanggal 26 Pebruari 2000 tentang Persyaratan dan Tata Cara Pemeriksaan Bank. 